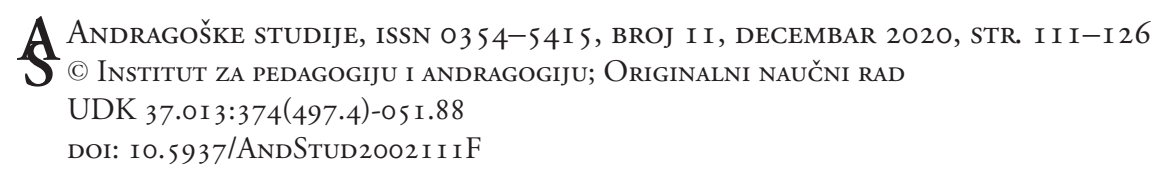

Meta Furlan ${ }^{1}$

University of Ljubljana, Slovenia

\title{
Older People's Transformative Learning in a Project Group
}

\begin{abstract}
A project group could be a foundation for a group members' transformative learning as older people in a project group foster learning, researching and acting publicly through cooperation. We see transformative learning as a key part of lifelong learning of older people because it does not only increase knowledge but also increases awareness of oneself and the local community. Transformative learning, however, may be seen as a way to help adults make sense of their experiences and make meaning of. In the article we will introduce theories of transformative learning, situated learning and biographical learning. Furthermore, we will think about the concept of ageing in place and examine the concept of inclusion of older people into society. The empirical part of the project explores the process of learning and education of older people through their active involvement into a project group of the international project Personal Town Tours. We found that participation in the project's activities and research of the city of Ljubljana are an incentive for transformative learning through place attachment.
\end{abstract}

Key words: transformative learning, biographical learning, situated learning, place attachment.

\section{Introduction}

Learning in later life brings new challenges in the field of culture, sustainable development, personal growth, active citizenship, etc., and with the acquired knowledge, it brings a change of beliefs, attitudes and values. It has an important emancipating role as it encourages older adults to critically evaluate their own situation and to retain control over their own lives and possibilities (Glendenning $\&$ Battersby, 1990). Learning in later life affects the quality of older people's lives as its impacts extend to the social, psychological, personal, economic, cultural, and civic spheres of life. A project group may facilitate the learning process and

\footnotetext{
${ }^{1}$ Meta Furlan is a young researcher at the Department of Educational Sciences, Faculty of Arts, University of Ljubljana (meta.furlan@ff.uni-lj.si).
} 
foster the development of transformative learning of older people in order to fulfil personal and professional lifelong learning (Yunga, 2019). Moreover, transformative learning can enhance older people's ability to become self-directed and to act upon assumptions and premises on which their performance, achievement, and productivity are based (Merriam \& Caffarella, 1999).

In the article, we will present the value of the project Personal Town Tours and the importance of participation of older people in international projects affecting transformative learning and, especially, the importance of involvement of older people in the local and international environment. The emphasis of our research was the learning of older people. We were interested in the learning and educational processes in the project group and the way its members regard the process of learning, cooperation, and exchange of views within the group.

\section{Learning of Older People through Ageing in Place}

The significance of place and place attachment have been discussed by many authors (Kellaher, Peace \& Holland, 2004; Peace, Holland, \& Kellaher, 2005; Lewicka, 2005; Casakin \& Neikrug, 2012). As philosopher Heidegger says (1958 in Relph, 2016, p. 1) "place places man in such a way that it reveals the external bonds of his existence and at the same time the depths of his freedom and reality." Place is perceived differently by each individual, depending on what the individual has experienced there, how one uses it and what it means to him. At this point, a reference can be made to the concept of place attachment, a multidimensional construct because of its physical, social, emotional, psychological and cultural aspects (Iecovich, 2014; Anton \& Lawrence, 2014; Ujang \& Zakariya, 2015). Place attachment is defined as the development of an affective bond between people or individuals and specific places expressed through the interplay of affects and emotions, knowledge and beliefs, and behavior and actions (Hidalgo \& Hernandez, 2001; Knez, 2005; Low \& Altman, 1992). It is the emotional tie that individuals develop with their place of residence, as well as other places (e.g. birthplace). Individuals attach to a place when that place is well-identified and felt significant by them and is able to provide the conditions to fulfil their functional needs and support their behavioral goals (Williams et al., 1992, in Ujang, 2012). As people age, they increasingly become attached to the place where they live, but concurrently become more sensitive and vulnerable to their social and physical environment. Rowles (1983, in Iecovich, 2014; 1983, in Wahl \& Oswald, 2013) developed a theory of "insideness" to conceptualize the attachment to a place, related to three dimensions: 1) physical insideness: living 
somewhere for long periods of time and developing a sense of environmental control by creating an idiosyncratic rhythm and routine; 2) social insideness: a social relationship that a person develops with others and is, therefore, known and knowing others; 3 ) autobiographical insideness: older people's attachment to a place because of the memories they have that shape their self-identity. Wahl and Oswald (2013) state that two processes are going on during place attachment. These are the process of belonging and the process of agency. The first one consists of the subjective experience with the place, such as interpretation, evaluation, signification, attachment, bonding and familiarity. It occurs primarily through experience that an individual has undergone in a certain place and through one's satisfaction with the living environment. In addition, the process of belonging develops through cognitive and emotional reflection of the place when an individual is giving meaning and importance to it. On the other hand, the process of agency underlines the objective experience with the place and is mostly goaloriented behavior, such as using, controlling, adapting, creating and sustaining. It goes in the direction of a sense of a place, control over the place and proactivity of older people (Wahl \& Oswald, 2013).

The concept of ageing in place includes the coexistence of older people in the community and their active involvement in it. The concept can be considered as the tendency of community development in the direction of openness to all generations and ensuring the quality of life for all members of the community. The research results (Wiler et al., 2011, in Iecovich, 2014) suggest that it is particularly important for older people to have a choice with regards to the living conditions, good access to resources, maintaining social ties, connecting with the local population, a sense of security and a sense of independence at home and in the community. In this context, we see the concept as very important in the direction of greater integration and acceptance of older people in the community. Moreover, it encourages older people to be active in shaping the community in which they live and to contribute to the community, which will be suitable and inclusive for all ages. Therefore, transformative learning occurs through the process of place attachment and aging in place as constructing, changing, and defining meaning of place. It is a lifelong process.

We can understand transformative learning as the process of using a prior interpretation to construct a new or revised interpretation of the meaning of one's experience in order to guide future action (Mezirow, 1996, in Taylor \& Cranton, 2013). Transformation embraces the idea that learning goes beyond quantifiable and recognizable territories questioning our understanding of the world when there is a challenge to our belief system (Cranton \& King, 2003). Transformative learning happens when critical reflection takes place: While the meanings are 
being reshaped, the frame of reference is being changed and an individual has the opportunity to place his or her experiences into a new or changed frame of reference (Fleischer, 2006). This means that what we build through critical reflection is subjective and personal and, therefore, very sensitive to changes. We should find out whether our newly constructed meaning is proper, so we, consequently, enter in a rational discourse with each other, allowing us to evaluate the reality of interpretations, beliefs, attitudes, etc. We conclude that rational discourse is the medium through which transformation is promoted and developed (Mezirow, 1997; Mezirow, 2003). Action is the last act of transformative learning. Without action, transformative learning does not have meaning because learning always has to have action as its goal. Transformative learning is oriented through the individual into society. It is oriented towards the change of the socio-cultural realities.

The individual's worldview is affected by personal experiences and they are very important for the individual's general orientation in the world. Life experience is formed on the basis of the individual's activity in the environment and on the basis of knowledge, which is obtained through one's activeness. Jarvis (2003, p. 100) equates biography with life experience, which he believes represents the totality of the individual's experience. Biographical learning, however, is not just one's own process, but it is also a social process and it could also be understood as learning one's life and learning from one's life (Biesta $\&$ Tedder, 2007). Alheit (2009) says that biographical learning is like an autopoietic process (a process that goes in the direction of self-production and self-building up) in which an individual learns from his biography and from one's life. An autopoietic system protects its autonomy and stores information in order to develop within itself and preserve its identity. Information is crucial for it, much like information about identity, experiences and emotions is crucial for the individual. This information is the basis for one's learning and it triggers the process of learning. Additionally, biographical learning encompasses the interest in the influence of biography on learning processes and practices, and the interest in biography itself as a field of learning (Alheit, 1995). On the other hand, Buschmeyer (1990, in GovekarOkoliš \& Ličen, 2008) believes that through biographical learning, an individual seeks various forms of identification and personal identity, so it involves different ways of learning: transformative, experiential and narrative.

Biographical, situated and transformative learning are inextricably linked. The experience and reflection are crucial for transformative and biographical learning. Hallqvist, Ellströmand Hydén (2012) suggest that biographical learning should be composed of two elements: reflexive identity and creative action. Reflexive identity represents the use of the individual's own life experience to maintain or improve his identity, while creative action represents the individual's 
planning of future activities and reflecting on his prior experiences in order to better understand his future, present and past actions. An individual incorporates one's narratives in his own life and work, therefore, has the possibility to evaluate past experiences and plan future activities. One's narratives represent a source of learning not only about history but also about life itself. Narratives were an important source for development of town tours based on personal narratives of project participants and inhabitants of Ljubljana. Those narratives were about different activities and situations happened in the city and their daily work. Learning is embedded in different situations we go through and, in fact, cannot be separated from everyday life and activities as the concept of situated learning assumes. Lave and Wenger (1991) assert that learning is part of an individual's activity and is a person's activeness in the community, whether that community is our family, friends, an organization, or leisure activities. They also claim that we are involved in many communities of practice in everyday life, where we are constantly learning, changing and developing, which is why learning is an integral and inseparable part of life (Wenger, 1998, 2009). Situated learning is informal, touching upon different areas, and requires one's responsibility for learning in different situations. Learning represents an individual's participation in different activities and social practices through which one constantly learns and shapes one's identity, although learning is often subconscious (Wenger, 1998, 2009). As stressed by Lave and Wenger (1991), we cannot focus only on the individual as an individual being, but primarily on the individual as a social being, as a member of the wider community. Learning involves the entire personality, therefore, it should never be viewed in isolation and we should never focus only on one specific activity. Schugurensky (2006) emphasizes that the majority of situated learning happens accidentally and unintentionally, and Foley (1999) adds that very important and interesting learning in the everyday life of people is informal and incidental.

Situated learning does not include only the learning of the individual but also the learning of the community. The community is being developed by the participation of individuals in communities of practice. We highlight the social dimensions of transformative learning, whereby learning is embedded in a place that is changing and reconstructing. If a community of practice is working to improve its activities, or to improve the community's life, or seeking solutions to the perceived problems, or developing new services, or exploring cultural heritage, the community is being changed together with the members of community of practice. The community is developed and, at some point, also reconstructed by the exhibition, publication, event and service. Change is what connects transformative and situated learning and, of course, we cannot avoid critical reflection or the dialogue, which are an integral part of any activity in the community. 


\section{Personal Town Tours Project}

The Personal Town Tours project was held at the Slovenian Third Age University from 2012 to 2014. The project was coordinated by Zentrum für Allgemeine Wissenschaftliche Weiterbildung of University of Ulm. The Slovenian Third Age University was one of the six partners involved in the project. The project was funded by the European Commission's Lifelong Learning Program.

The purpose of the project was to train older people to become tour guides of their home towns. The project led to the development of cultural tours that can be offered to national and international guests. In Slovenia, eight older people were involved in the project group. Their mentor was Meta Kutin, a young architect and mentor of the study circle at the Slovenian Third Age University. Tours were developed on the basis of the participants' interests in art, architecture, history, cultural heritage, urban planning and their subsequent research in archives, libraries and oral history reports obtained via interviews and narratives by the project group. Members of the project group developed three town tours:

- Following the Trace of Lettuce: The stories of the lettuce named "Krakovo Salat" and the famous Slovenian architect Jože Plečnik are presented in this town tour. Krakovo is the home of the architect. The Krakovo settlement is full of storytelling of its dwellers who grew vegetables and transported them by cart along the Ljubljanica River to Ljubljana's open market, which is named after the architect Jože Plečnik.

- Dwelling Culture: The part of Ljubljana called Murgle is presented in this tour as it is known by low densely built-up settlements of singlefamily atrium homes open to nature and by streets named after trees. Living in the Murgle neighborhood brings an interesting connection between urban living and nature.

- Meetings-Between Culture and Friends: At the beginning of the $20^{\text {th }}$ century, citizens used to exchange their impressions, ideas and views related to cultural events in city coffeehouses. These places are, therefore, associated with numerous stories from the cultural sphere. The ambiances of the city's past as well as present gathering places which gave birth to creative ideas are presented in this tour.

Members of the project group focused on their personal narratives and impressions of anonymous inhabitants of Ljubljana. They were eager to discover how they see their city, how visitors see it and how the official history takes part in individual stories. They introduced the city of Ljubljana in an informal and 
original way, avoiding repeating stories described in chronicles. Instead, they focused on their daily activities, such as gardening and growing vegetables, boating on the river, walking around, chatting with friends over a cup of coffee in the city's cafés or taking a rest in a home atrium. Thus, Ljubljana is shown in a unique way-from the perspective of older people, who have been living in Ljubljana for a long time. A lot of different topics can leave a genuine impression of Ljubljana when presented personally. Additionally, a personal presentation contributes to better understanding the respective city and its life and culture.

The project group of the Personal Town Tours project was the primary focus in our research. We have assumed that the project group is the place of learning, and personal and community development, therefore we researched whether the project groups were incentives for transformative, biographical and situated learning. We were interested in the learning and education processes in the project group and in the way the members regarded the processes of learning, cooperation, and exchange of views within the group. Besides this, we wanted to find out three things. First, we wanted to know whether the involvement in the project provided the foundation for group members' transformative learning. Second, we wanted to observe the different ways in which the project encouraged the engagement of older people in their local environment and affected the conceptualization of active old age. And third, we were interested in the way the fact that the project and the research itself were conducted in the living quarters of older people affected the course and the results of the research.

\section{Methodology}

The research is based on the empirical data of the international project Personal Town Tours. The research was conducted in 2015, one year after the completion of the international project Personal Town Tours. The employment of qualitative methodology with a case study approach and a multi-method strategy was dictated by the nature of the research questions that explore learning processes, place attachment, and older people's involvement.

\section{Sample}

The sample for this research was chosen from the project group of the international project Personal Town Tours taking place between 2012 and 2014 at the Slovenian Third Age University. Eight older people participated in the project group and four of them (three female participants and one male participant) were 
chosen to conduct semi-structured interviews with them. The interviewees were between 60 and 80 years old.

\section{Data Collection}

The employed methods for the fieldwork data-collections were interviews, observations, and visual and documentary modes. Interviews took place in April and May 2015. They were conducted individually; each took approximately 60 to $90 \mathrm{~min}$ utes. We also conducted several observations that purposefully covered most of the project group's work. These observations were matched with different parts of the project such as the pilot town tours, the project group meetings, the tour guiding, discussions with interest group members, etc. Visual methods and documentary sources were intended both to complement the previously described methods as well as to provide a separate strand of data. The documentary methods included written narratives on the reasons for choosing a particular theme for the exploration and development of town tours by all project group members as well as members' presentations and descriptions of the town tours. The visual methods included video clips from the project presentation at the Urban Planning Institute of the Republic of Slovenia and the photography exhibition about Ljubljana held at the Slovenian Third Age University mounted by members of the project group.

\section{Data Analysis}

We used thematic analysis method (Mesec, 1998) to deal with the collected data. Data collected from the interviews, video clips, and the written narratives was transcribed and analyzed within the aforementioned theoretical framework. The content analysis was inductive: it included open coding as well as creating categories and abstractions to enable data comparison and interpretation.

\section{Results}

\section{Place attachment}

The analysis of the interviews shows that the members of the project group are attached to Ljubljana because they all expressed their close relationship with the city. Attachment to the city is built through the physical dimension of space (houses with an atrium in Murgle, the Ljubljanica River), the emotional psy- 
chological dimension (memories, anecdotes, activities) and the social dimension (contact with students, neighbors, communication with costermongers on the market). Their life story was built through outdoor and indoor activities, service use, use of public space and neighborhood life; knowing that, we can claim that a place maintains the social identity. All of the members' memories are associated with a place and people, without whom they would not be themselves. A person develops in contact with others and with a place-an individual in an empty place does not exist.

"What has marked me for all of my life? Life and the love of nature, which I have inherited from my parents and grandparents. My father was a forester and hunter all his life and has always been strongly connected with nature and living in it. I have found all this passion and love in Murgle, in this house where I have lived since 1985. The quality of living in this part of our city has met my expectations and compensated for the "splendors" of the place where I spent my childhood."

Stokols and Shumaker (1981, in Livingston, Bailey \& Kearns, 2008) say that we are attached to the place in a functional and in an emotional way, which can be confirmed by our research. The interviewees expressed that they were given opportunities by the place that has met their expectations, by enjoying the place, acquiring new knowledge about the place, etc. Additionally, they are attached to the place with a lot of memories, feelings, emotions and moods, which indicates their emotional attachment.

"Ljubljana, considered by many as one of the most beautiful cities, is my city. I feel this way walking through its streets, squares and parks, and reminiscing about pleasant walks in the Botanical Garden with my mother, who taught me to appreciate nature and enjoy it."

Experiencing the place is always subjective and is related to past experiences and actions. Here we can refer to Relph (2016), who believes that home is a significant part of older people's identity because of the length of time living there and the amount of experiences and, therefore, has a significant impact on the quality of life in old age. We found that the project group members identify with Ljubljana and feel a special kind of fondness towards it. Some of them have experienced first love in Ljubljana, as one member revealed. She had found in the Ljubljanica River a quiet romance and nostalgia in her younger years: "Walks to Rožnik Hill will be stamped on my memory forever because I have pleasant memories of how we kids competed among ourselves who will be the first to reach the Church of the Visitation on this hill." 
We argued, therefore, that their place of residence has become an extension of themselves. A member of the project group emphasized that each individual must have a home somewhere because without it, one is lost. Home is irreplaceable, he says. We agree with his opinion because home gives us some sort of security, not only physical, but also psychological: It allows us to know who we are, in what aspects we are different from others, in what aspects we can be compared with others, and allows us to build our self-esteem and self-confidence (Livingston et al., 2008).

We claim that the fact that the project and the research itself were conducted in the living quarters of the interviewees greatly affected the course and the results of the research. We have found that the selection of tours originated in: a) personal attitude towards Ljubljana; b) personal experience of nature, paths and childhood; c) knowledge and use of the city; d) use of public spaces; e) narratives of friends, colleagues, family and neighbors; f) daily city activities; g) personal stories and memories.

\section{Learning process}

Based on the analysis of the interviews, we found that biographical learning encourages exploring roots, history and family stories. Buschmeyer (1990, in Govekar-Okoliš \& Ličen 2008) states that an individual also uses biographical learning to discover his personal identity. One member says that the fundamental questions are hidden in art: where we come from, who we are and where we are going. These were the central questions in her youth. Only through the exploration of the Opera (she and her parents worked there), where she spent her childhood, youth and adulthood, she began to wonder who she is. Her family has been closely linked to the Opera and, as she says, she did not know much about it until the beginning of the project. Researching the colleagues' narratives and literature she was able to get to know the Opera and this research has also become a process of learning family history and narratives:

"Because of her profession (art historian, curator and documentarian), my sister Eva is a source of family stories, which I know poorly. Reminiscing with her about the past opened a new world to me and turned me back to the old stories of my grandparents and great-grandparents, and led me to the question: Where do I come from?"

The development of town tours and, consequently, the acquirement of new knowledge was not only limited to the project group's meetings. On 
the contrary, it has been integrated into the daily lives of the members of the project group. New insights on topics, new ideas, new findings and inspirations emerged in the variety of everyday activities and situations. Considering Wenger and Lave's (Wenger, 1998, 2009) theory of situated learning, which states that learning is embedded in an individual's every activity and is, therefore, part of his community activities, we can argue that situated learning took place in the project. For the members of the group, participating in the Personal Town Tours meant spontaneous learning, caused with their active participation in the project group. Lave and Wenger (1991) have emphasized that we should always look at an individual as a social being, a being that is always socially constructed and embedded in various aspects of social life. Therefore, learning cannot be isolated or focused only on one activity, but is scattered in various individual and social activities and a person is continuously engaged in the learning process. The interviewees have been involved in the learning process continuously, directly or indirectly, whether in the study groups of the Third Age University study circle, drinking coffee in the Tivoli Opera House, studying at home in the Murgle area, etc.

We discovered that transformative learning could be found in all forms of learning during the project. Transformative learning is most clearly seen in the case of $\mathrm{Z} 1$ and his changed experience of his childhood route to Trnovo. He evaluated this experience and gave it a new meaning through researching the Trnovo district:

"In my middle age, I had an opportunity to listen to a lecture of an architect speaking about Plečnik's work and its importance for Ljubljana. My youthful perception of the Trnovo path has been changed by this lecture. The houses and monuments along the path have acquired a new meaning and have become a reminder of the times due to the new knowledge about their history and Plecnik. My journey from childhood was so filled with messages. Today, in the third stage of life, my perception of the path is full of new meanings and visions. The perception of my aunt's cherry trees and the swimming pool in Kolezija became even more rich and meaningful. I experience specific characteristics of urban streets in a different way now."

Self-reflection is very important according to transformative learning: reflection of one's own experience and action, which is then extended to the social level. An individual cannot act towards changing the society without self-discovery and development because reflecting on one's own beliefs, attitudes and values is missing. Project group members derived from precisely this 
aspect. Firstly, they originated from themselves: from their personal experience of Ljubljana, their daily activities and personal biographies. In the second step of the research, they extended the research to the inhabitants of Ljubljana. Finally, all findings, narratives, photographs and ideas were combined and formed into three town tours, covering both personal and architectural aspects. Town tours, a photo exhibition, posters and publications were their actions, with which they entered the public domain. They started a dialogue with the public to discuss urbanism and architecture as well as the importance of experiencing the city. We cannot stress enough that a city cannot exist without the narrative of its inhabitants, without place attachment and without the inhabitants' attitude towards it. The city and its residents are increasingly interdependent, co-creating each other.

\section{The effects of participation in the project on the individual and the local community}

Members of the project group easily recognized the effect of their participation on themselves, but showed poor recognition of the effect on the local community. One member stated that her research helped improve communication among neighbors and their involvement in storytelling and monitoring the project results. Another member stated that her family finally accepted her active ageing and they do not complain anymore. Generally, they feel the project results (town tours, publication and exhibition) are important for Ljubljana and its tourist offer, but they are poorly recognized. The effects of participation in the project for the interviewees include better communication in foreign languages, acquiring new knowledge, easier speaking in public and tour guiding, personal development and greater self-confidence, and better teamwork as well.

\section{Conclusion}

The theory of transformative learning is one of the most developed theories in adult education because it prospers to address issues exclusive to adult learners such as the ability to reflect critically on experiences, integrate this knowledge into existing knowledge structures, and take action on these insights (Leong Kappel \& Daley, 2004, p. 83). Such was the work in the project group of the international project Personal Town Tours. The older people, members of the project group, discovered and researched Ljubljana and its stories in various ways: inde- 
pendently by reading literature and searching for archival articles in the National and University Library, they collaborated in creating topics and tours, they researched their own history, they evaluated their stories, experiences and visions of Ljubljana, they designed a photo exhibition and published a tourist guide and presented their work in partner countries.

We took the transformative learning model as an umbrella model, as we believe that changing attitudes, beliefs, assumptions, views, stereotypes, and emotions relating to one's own personality as well as architecture, history, urban space and one's participation in the local community was one of the most pronounced and intense. We claim that the participation in the Personal Town Tours project was an incentive for transformative learning. We have found that biographical and situated learning took place among project group members, while critical reflection and dialogue were central in changing their beliefs about themselves, their colleagues and their perception of Ljubljana.

We have found that not only were the project group members changed, but also their families and friends, indirectly also the city. Project group members spoke publicly about their activities, exploring the city and other actions. They pointed to the fact that the city is not the property of decision makers but is mostly in the hands of its inhabitants. They have entered in a dialogue with the local community about the city experiences and its importance for the inhabitants of Ljubljana. Moreover, they dispelled stereotypes about older people with their activeness and raised the awareness about the importance of including older people in the community.

We believe that international projects are an opportunity for greater involvement of older people in a local and international environment, a source of learning and a journey of self-discovery and self-development. They are also important from the perspective of building a European identity, breaking stereotypes and prejudices of different nationalities and promoting cooperation in a local and wider community. Participation of older people in international projects is very important for them as well as for their families, friends and the wider community. We believe, therefore, that international projects are very welcome in older adult education, thereby enriching their knowledge which is passed on to their local community. Ultimately, in today's society when transferability and mobility are high on the current agenda, jarring changes at points in an older learner's life are inevitable (Yunga, 2019). Transformative learning theory is therefore important and well-situated to the current European politics of active ageing and knowledge-based society. 


\section{References}

Alheit, P. (1995). Biographical learning: Theoretical outline, challenges and contradictions of a new approach in adult education. In P. Alheit, A. Bron-Wojciechowska, E. Brugger and P. Dominicee (Eds.), The Biographical Approach in European Adult Education (pp. 57-74). Wien: Verband Wiener Volksbildung.

Alheit, P. (2009). Biographical learning - within the new lifelong learning discourse. In K. Illeris (Ed.), Contemporary theories of learning (pp. 116-128). New York, Oxon: Routledge.

Anton, C. E., \& Lawrence, C. (2014). Home is where the heart is: The effect of place of residence on place attachment and community participation. Journal of Environmental Psychology, 40, 451-461.

Biesta, G., \& Tedder, M. (2007). Agency and learning in the lifecourse: Towards an ecological perspective. Studies in the Education of Adults, 39(2), 132-149.

Casakin, H., \& Neikrug, S. (2012). Place Identity in the Neighbourhood as Perceived by the Elder Residents: Relations with Attachment, Dependence and Place Quality. In H. Casakin \& F. Bernardo (Eds.), The Role of Place Identity in the Perception, Understanding, and Design of Built Environments (pp. 92-106). Oak Park: Bentham Science Publishers.

Cranton, P., \& King, K. P. (2003). Transformative learning as a professional developmental goal. New Directions for Adult and Continuing Education, 98, 31-38.

Fleischer, B. J. (2006). Mezirow's Theory of Transformative Learning and Lonergan's Method in Theology: Resources for Adult Theological Education. The Journal of Adult Theological Education, 3(2), 147-162.

Foley, G. (1999). Learning as social action: A contribution to understanding informal learning. New York: Zed Books.

Glendenning, F., \& Battersby, D. (1990). Why we need educational gerontology and education for older adults: A statement of first principles. In F. Glendenning \& K. Percy (Eds.), Ageing, education and society: Readings in educational gerontology (pp. 219-231). Keele, Staffordshire: Association for Educational Gerontology.

Govekar-Okoliš, M., \& Ličen, N. (2008). Poglavja iz andragogike. Ljubljana: Znanstvena založba Filozofske fakultete Univerze v Ljubljani.

Hallqvist, A., Ellström, P. E., \& Hydén, L. C. (2012). The many faces of biographical learning. Studies in the Education of Adults, 44(1), 70-84.

Hidalgo, M. C., \& Hernandez, B. (2001). Place Attachment: Conceptual and Empirical Questions. Journal of Environmental Psychology, 21(3), 273-281.

Incovich, E. (2014). Aging in place: From theory to practice. Anthropological Notebooks, 20(1), 21-33.

JaRvis, P. (2003). Izkušenjsko učenje in pomen izkušnje. Sodobna pedagogika, 54(1), 94-103.

Kellaher, L., Peace, S. M., \& Holland, C. (2004). Environment, identity and old age quality of life or a life of quality? In A. Walker \& C. Hagan Hennessy (Eds.), Growing Older. Quality of life in old age (pp. 60-80). New York: Open University Press. 
KneZ, I. (2005). Attachment and identity as related to a place and its perceived climate. Journal of Environmental Psychology, 25(2), 207-218.

Lave, J., \& Wenger, E. (1991). Situated Learning. Legitimate Peripheral Participation. United Kingdom: The Press Syndicate of the University of Cambridge.

Leong Kappel, P., \& Daley, B. J. (2004). Transformative Learning and the Urban Context. New Directions for Adult and Continuing Education, 101, 83-94.

LEWICKA, M. (2005). Ways to make people active: Role of place attachment, cultural capital and neighbourhood ties. Journal of Environmental Psychology, 4, 381-395.

Livingston, M., Bailey, N., \& Kearns, A. (2008). People's attachment to place - the influence of neighbourhood deprivation. Glasgow: The Joseph Rowntree Foundation.

Low, S. M., \& Altman, I. (1992). Place attachment: A conceptual inquiry. In S. M. Low \& I. Altman (Eds.), Place attachment (1-12). New York: Plenum Press.

Merriam, S. B., \& Caffarella, R. S. (1999). Learning in Adulthood. San Francisco: Jossey-Bass Publishers.

Mesec, B. (1998). Uvod v kvalitativno raziskovanje v socialnem delu. Ljubljana: Visoka šola za socialno delo.

Mezirow, J. (1997). Transformative Learning: Theory to Practice. New Direction for Adult and Continuing Education, 74, 5-12.

Mezirow, J. (2003). Transformative Learning as Discourse. Journal of Transformative Education, 1(1), 58-63.

Peace, S. M., Holland, C., \& Kellaher, L. (2005). Making space for identity. In G. J. Andrews \& D. R. Phillips (Eds.), Ageing and Place: Perspectives, policy, practice (pp. 188-206). London and New York: Routledge.

Relph, E. (2016). Place and Placelessness. Los Angeles, London, New Delphi, Singapore, Washington DC: SAGE Publications.

Schugurensky, D. (2006). This is our school of citizenship: Informal learning in local democracy. Counterpoints, 249, 163-182.

Taylor, W. E. And Cranton, P. (2013). A theory in progress? Issues in transformative learning theory. European Journal for Research on the Educational and Learning of Adults, 4(1), 33-47.

Ujang, N. (2012). Place Attachment and Continuity of Urban Place Identity. ProcediaSocial and Behavioral Sciences, 49, 156-167.

Ujang, N., \& ZakariYa, K. (2015). Place Attachment and the Value of Place in the Life of the Users. Procedia - Social and Behavioral Sciences, 168, 373-380.

WAHL, H. W., \& Oswald, F. (2013). Environmental Perspectives on Ageing. In D. Dale \& C. Phillipson (Eds.), The Sage Handbook of Social Gerontology (pp. 111-124). London, Thousand Oaks, New Delhi, Singapore: Sage Publications.

Wenger, E. (1998). Communities of Practice. Learning, Meaning and Identity. United Kingdom: Cambridge University Press.

Wenger, E. (2009). A social theory of learning. In K. Illeris (Ed.), Contemporary theories of learning (pp. 209-218). New York, Oxon: Routledge.

Yunga, D. C. (2019). Transformative Learning: The Richness of Formality and Informality. Andragoške studije, 2, 69-91. 
Meta Furlan ${ }^{2}$

Univerzitet u Ljubljani, Slovenija

\section{Transformativno učenje starijih ljudi u okviru projektne grupe}

Apstrakt: Projektna grupa bi mogla da predstavlja temelj za transformativno učenje članova grupe, budući da stariji ljudi u projektnim grupama putem saradnje neguju učenje, istraživanje i javno delovanje. Transformativno učenje smatramo izuzetno značajnim u okviru celoživotnog učenja starijih ljudi jer ne samo da poboljšava znanje, već ujedno unapređuje svest o sebi i lokalnoj zajednici. Međutim, transformativno učenje se može smatrati sredstvom koje odraslim ljudima pomaže da njihova iskustva zadobiju smisao i da ih shvate. U ovom radu ćemo predstaviti teorije transformativnog učenja, situacionog učenja i biografskog učenja. Uz to, razmotrićemo koncept starenja u poznatom okruženju $\mathrm{i}$ ispitati koncept uključivanja starijih ljudi u društvo. U empirijskom delu projekta istražuje se proces učenja i obrazovanja starijih ljudi kroz njihovo aktivno uključivanje u projektnu grupu u okviru međunarodnog projekta „Personal Town Tours“. Zaključili smo da su učešće u projektnim aktivnostima i istraživanju Ljubljane podsticaj za transformativno učenje kroz vezanost za mesto.

Ključne reči: transformativno učenje, biografsko učenje, situaciono učenje, vezanost za mesto.

\footnotetext{
${ }^{2}$ Meta Furlan je mladi istraživač na Katedri za obrazovne nauke Fakulteta društvenih nauka Univerziteta u Ljubljani (meta.furlan@ff.uni-lj.si).
} 